\title{
Isolation and characterization of polymorphic microsatellite markers from Coilia ectenes
}

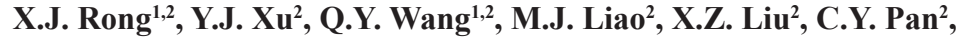 \\ Z. Zhang ${ }^{2}$ and Y.G. Wang ${ }^{2}$ \\ ${ }^{1}$ Ocean University of China, Qingdao, China \\ ${ }^{2}$ Qingdao Key Laboratory for Marine Fish Breeding and Biotechnology, \\ Yellow Sea Fisheries Research Institute, Chinese Academy of Fishery Sciences, \\ Qingdao, China \\ Corresponding author: Y.G. Wang \\ E-mail: wangyg@ysfri.ac.cn
}

Genet. Mol. Res. 12 (4): 6011-6017 (2013)

Received July 4, 2013

Accepted November 11, 2013

Published November 26, 2013

DOI http://dx.doi.org/10.4238/2013.November.26.11

\begin{abstract}
Coilia ectenes (Jordan and Seale 1905) is an important anadromous species that is an important resource at risk of extinction because of over-fishing, pollution, and coastal construction. To evaluate the genetic diversity of $C$. ectenes for use in breeding programs, elite microsatellite-enriched libraries were constructed and novel microsatellite markers were developed, and applied to genetically detect wild populations. Out of 92 randomly selected and sequenced clones, 89 contained a CA or GA repeat motif. Twenty-two pairs of primers were designed to investigate the polymorphism and genetic structure of a wild population collected from the Yellow River estuary, China. It was found that 2 loci were monomorphic and 20 loci were polymorphic. The number of alleles per polymorphic loci ranged from 3 to 13, with an average of 7.9. The expected heterozygosity per locus ranged from 0.05 to 0.89 , with an average of 0.68 . The isolated polymorphic markers are expected to be of use in future genetic breeding programs for C. ectenes,
\end{abstract}


and in the assessment of genetic variation within this species.

Key words: Coilia ectenes; Microsatellite marker; Genetic diversity

\section{INTRODUCTION}

Coilia ectenes (Jordan and Seale 1905) is a commercially important small-to moderate-sized anchovy that inhabits a wide area, including the northwest and western Pacific Ocean, and extending southward toward Canton in southern China and northward to the Ariake Sound of southwestern Japan, including all of the Yellow Sea and the area off the western coast of Korea (Whitehead et al., 1988). C. ectenes is an anadromous species; whereby, during the spawning season, individuals migrate annually from coastal waters to freshwater areas (Li et al., 2007). In China, four Coilia species have been identified by taxonomists: Coilia grayii, C. ectenes, Coilia mystus, and Coilia brachygnathus (Feng, 1997). However, the current taxonomic status of Coilia fishes remains unclear, with issues over the classification of $C$. ectenes and $C$. ectenes taihuensis, despite extensive effort to establish clear distinctions using traditional meristic, ecological, and physiological methods (Yuan et al., 1976; Liu, 1995; Cheng and Han, 2004; Cheng et al., 2005a) and genetic analyses (Cheng et al., 2005b, 2008; Ma et al., 2011). Thus, it is necessary to determine the genetic background of $C$. ectenes to clarify the taxonomy of Coilia species.

The flesh of $C$. ectenes is delicious and nutrient-rich; thus, it is a popular table food of Chinese consumers. In China, C. ectenes is mainly distributed in Qiantang River, the Yangtze River, the Yellow River, the Liaohe River, and several other rivers that connect with the East China, the Yellow, and the Bohai Seas (Yuan, 1980; Yuan and Qin, 1984). This species is used to support important commercial fisheries in China. However, over-fishing, pollution, coastal construction, and a number of other factors have caused a dramatic decline in the landings of $C$. ectenes in recent decades; consequently, this species represents a fishery resource that is on the verge of exhaustion. Thus, there is an immediate requirement to protect this important fishery species in China through various strategies, including fisheries resource assessments, the environment protection of its habitats, and artificial breeding programs for aquaculture. These strategies would contribute towards the sustainable use and management of this important fisheries resource.

Microsatellite markers are valuable tools for studying the genetic composition and variation in a given population. In addition, microsatellites are one of the most polymorphic and effective types of markers for disclosing the genetic diversity and divergence within or between populations. Furthermore, these markers have been proved to be an extremely important tool for genetics studies, as well as in the conservation and management of genetic resources. To date, there are two papers reported to isolate microsatellite markers for C. ectenes (Ma et al., 2011; Chen et al., 2012), but the amount of microsatellite is still not enough for assessments about the population structure, molecular phylogeny, and molecular assisted selective breeding of this commercially important fish species. Thus, development of new microsatellite markers for C. ectenes is anticipated to facilitate the development of sustainable fishing strategies, and potential artificial breeding programs of this important fish species. 


\section{MATERIAL AND METHODS}

\section{Sample collection DNA extraction}

Sixty individuals of C. ectenes were collected from the Yellow River estuary in China. Samples were preserved in alcohol until DNA extraction. Genomic DNA was extracted from Fin clips using an E.Z.N.A ${ }^{\circledR}$ Tissue DNA Kit (Omega, Norcross, USA). The extracted genomic DNA was examined by electrophoresis on agarose gel and stored at $-20^{\circ} \mathrm{C}$ until genotyping.

\section{Microsatellite-enriched library construction}

A microsatellite-enriched library was constructed using the FIASCO (Fast Isolation by AFLP of Sequences Containing Repeats) method, which is described in detail by Zane et al. (2002), but with minor modifications, which were described in detail by Liao et al (2007). In brief, genomic DNA was digested with $M$ seI enzyme (Sangon, Shanghai, China) at $37^{\circ} \mathrm{C}$ for 4 $\mathrm{h}$, and ligated with a synthesized $M s e \mathrm{I}$ adaptors (5'-TAC TCA GGA CTC AT-3'/5'-GAC GAT GAG TCC TGA G-3') using T4 DNA ligase (Sangon, Shanghai, China). The digestion-ligation mixture was amplified using the adaptor-specific primer (5'-GAT GAG TCC TGA GTA A-3'). Microsatellite-containing fragments were selectively enriched, captured, and washed using biotinylated-(CA) ${ }_{12}$ and Streptavidin Magnetic Sphere ${ }^{\circledR}$ Paramagnetic Particles (Promega, Madison, USA). Fragments containing microsatellites were ligated with the pMD18-T vector (TaKaRa, Dalian, China), and transferred into E. coli competent cell JM109 (TaKaRa, Dalian, China) by electroporation.

\section{Isolation of microsatellite-containing DNA fragments and primer design}

To check whether the microsatellite motif was located in the middle of the insert, each recombinant was subjected to 3 separate PCR screenings using 2 universal sequencing primers and the $(\mathrm{CA})_{12} \mathrm{DN}$ oligonucleotide. In the first reaction, universal forward and universal reverse sequencing primers were used. In the second reaction, a universal forward sequencing primer and $(\mathrm{CA})_{12} \mathrm{DN}$ oligonucleotide were used. In the third reaction, a universal reverse sequencing primer and $(\mathrm{CA})_{12} \mathrm{DN}$ oligonucleotide were used. Recombinant clones that produced products of obviously different lengths between the first, second, and/or third reactions were sequenced and trimmed. The sequencing data were scanned using the software SSRHunter V1.3 (Li and Wan, 2005). Sequences with microsatellite motifs and flanking regions were selected for PCR primer design by Primer Premier.

\section{PCR amplification and genotyping}

The designed microsatellite primers were used to amplify the genomic DNA of 60 C. ectenes individuals. The PCR mixture contained $1 \mathrm{X}$ buffer, $1.5 \mathrm{mM} / \mathrm{L} \mathrm{MgCl} 2,200 \mu \mathrm{M} / \mathrm{L}$ dNTP (each), $200 \mu \mathrm{M} / \mathrm{L}$ primer (each direction), and about 50 -80 ng genomic DNA. The PCR conditions were: denaturing at $94^{\circ} \mathrm{C}$ for $1 \mathrm{~min}$, followed by 30 cycles of $1 \mathrm{~min}$ at $94^{\circ} \mathrm{C}, 1 \mathrm{~min}$ at annealing temperature, and $1 \mathrm{~min}$ at $72^{\circ} \mathrm{C}$, with a final extension for $5 \mathrm{~min}$ at $72^{\circ} \mathrm{C}$. The PCR product was separated on $6 \%$ denaturing polyacrylamide gel and visualized by silver staining. 
Allele size was determined with the Quantity One V4.62 software (Bio-Rad, Hercules,CA, USA) by referring to a 20-bp DNA ladder marker (TaKaRa, Dalian, China).

\section{Genetic data analysis}

POPGENE version 1.32 (Yeh et al., 1999) was used to calculate the number of alleles $\left(N_{\mathrm{A}}\right)$, the number of effective alleles $\left(N_{\mathrm{E}}\right)$, observed heterozygosity $\left(H_{\mathrm{O}}\right)$, and expected heterozygosity $\left(H_{\mathrm{E}}\right)$. The polymorphism information content (PIC) of each locus was calculated according to Botstein et al. (1980). The Hardy-Weinberg equilibrium and linkage disequilibrium tests were conducted using the online version of Genepop (Rousset, 2008). Significance criteria of all multiple tests were corrected following sequential Bonferroni correction (Rice, 1989).

\section{RESULTS AND DISCUSSION}

Out of 200 randomly selected recombinant clones, 92 (46\%) contained inserts with a microsatellite motif in the middle position, indicating that enrichment was highly effective. Of the 92 clones surviving PCR screening, 89 (70.6\%) contained a microsatellite motif in the middle position after being sequenced (Table 1). The sequences were divided into 3 categories following the classification rules developed by Weber (1990): 1) 58 perfect repeat sequences without interruptions in the runs of CA or GT di-nucleotides (65.2\% of total), 2) 27 imperfect repeat sequences with 1 or more interruptions in the run of repeats (30.3\%), and 3) 4 compound repeat sequences with adjacent tandem simple repeats of a different sequence (4.5\%). When classified using the repeat sequence type, all clones had di-nucleotide repeats, of which the repeat number of 41 clones was between 5 to 9 , while the repeat number of 48 clones was higher than 10 .

Table 1. Classification of microsatellite DNA sequences obtained in this study.
\begin{tabular}{llrr}
\hline Criterion & Category & No. of sequences & Percentage (\%) \\
\hline Weber (1990) & Perfect & 58 & 65.2 \\
& Imperfect & 27 & 30.3 \\
Repeat motif & Compound & 4 & 4.5 \\
& Two bases $5 \leq \mathrm{n} \leq 9$ & 41 & 46.1 \\
& Two bases $\mathrm{n} \geq 10$ & 48 & 53.9 \\
\hline
\end{tabular}

In the first batch, 22 primer pairs were designed based on 30 sequences, and used to investigate the polymorphism of 60 C. ectenes individuals. Of the 22 primer pairs tested, 20 loci showed clear band patterns and polymorphism (Table 2). A total of 159 alleles were detected at 20 loci, with a total of 93 effective alleles. The $N_{A}$ at each locus ranged from 3 (HD28 and HD 118) to 13 (HD25), with an average of 7.9. The $N_{E}$ ranged from 1.1 (HD118) to 8.9 (HD25), with an average of 4.6. The difference between $N_{A}$ and $N_{E}$ was caused by the uneven frequency of each allele. The relationship between the number of microsatellite repeats and polymorphism is subject to debate. Qu et al. (2010) suggested that the polymorphism would be higher when the number of microsatellite repeats increased. Alternatively, Zheng et al. (2008) suggested that many high polymorphic loci would be missed if only loci with high numbers of microsatellite repeats were chosen in genetic research. The results of the current experiment showed that there is no relationship between the num- 
ber of microsatellite repeats and polymorphism, which was consistent with Zheng et al. (2008).

\begin{tabular}{|c|c|c|c|c|c|c|c|c|c|c|c|}
\hline locus & $\begin{array}{l}\text { Accession } \\
\text { No. }\end{array}$ & Repeat motif & Primer sequence $\left(5^{\prime} \rightarrow 3^{\prime}\right)$ & $\begin{array}{l}\text { Size range } \\
\text { (bp) }\end{array}$ & $\begin{array}{l}\mathrm{Tm} \\
\left({ }^{\circ} \mathrm{C}\right)\end{array}$ & $N_{\mathrm{A}}$ & $N_{\mathrm{E}}$ & $H_{\mathrm{O}}$ & $H_{\mathrm{E}}$ & PIC & $P$ \\
\hline HD4 & KC506602 & $(\mathrm{CA})_{14}$ & $\begin{array}{l}\text { F: CGCTGAGCTGATGGTTTG } \\
\text { R: GACCCAGTAACCTCATACACCT }\end{array}$ & $320-345$ & 58 & 7 & 3.2 & 0.53 & 0.69 & 0.64 & 0.0338 \\
\hline HD8 & KC506603 & $(\mathrm{CA})_{12}$ & $\begin{array}{l}\text { F: AATCACAACAAGCGCAATC } \\
\text { R: GCAATGACCCTTTCCTTC }\end{array}$ & $86-145$ & 54 & 12 & 8.2 & 0.49 & 0.88 & 0.87 & $0.000^{*}$ \\
\hline HD9 & KC506604 & $(\mathrm{CA})_{5}$ & $\begin{array}{l}\text { F: TGCTCTTGACATATCGAAGG } \\
\text { R: TGGGATTTGTCAGGGAGA }\end{array}$ & $155-186$ & 54 & 10 & 3.7 & 0.50 & 0.73 & 0.70 & $0.000 *$ \\
\hline HD16 & KC506605 & $(\mathrm{AC})_{7}$ & $\begin{array}{l}\text { F: CACAGCTCCCGTGGCTCAA } \\
\text { R: AGGCGAGGAGGCGGTATGAG }\end{array}$ & $88-98$ & 63 & 5 & 1.7 & 0.49 & 0.40 & 0.35 & 0.9975 \\
\hline HD25 & KC506606 & $\begin{array}{l}(\mathrm{CA})_{8}(\mathrm{AC})_{14} \\
(\mathrm{CA})_{14}\end{array}$ & $\begin{array}{l}\text { F: ACTCTAACCTTCTCACCTGCTA } \\
\text { R: GGGTGAAGGGAAAAGTGT }\end{array}$ & $173-217$ & 55 & 13 & 8.9 & 0.55 & 0.89 & 0.88 & $0.000 *$ \\
\hline HD28 & КС506607 & $(\mathrm{CA})_{8}$ & $\begin{array}{l}\text { F: GACACTTGCGTATTTCCG } \\
\text { R: CTGGGAGACACTTTGCTG }\end{array}$ & $187-193$ & 55 & 3 & 2.0 & 0.71 & 0.50 & 0.40 & 0.9882 \\
\hline HD30 & КC506608 & $(\mathrm{CA})_{16}$ & $\begin{array}{l}\text { F: GCCAACTGTCCTCCAACC } \\
\text { R: GTGCGTGCGTGTAGGTGT }\end{array}$ & $165-188$ & 59 & 8 & 2.5 & 0.18 & 0.60 & 0.58 & $0.000^{*}$ \\
\hline HD40 & КC506609 & $(\mathrm{CA})_{7}(\mathrm{AC})_{8}$ & $\begin{array}{l}\text { F: TCTAAGCCCAACCAAAAAAAGATAA } \\
\text { R: TAAGGACGAGGCGGGACAGG }\end{array}$ & $622-640$ & 58 & 5 & 3.5 & 0.64 & 0.72 & 0.67 & 0.0159 \\
\hline HD42 & KC506610 & $(\mathrm{AC})_{13}$ & $\begin{array}{l}\text { F: GCTGACGGCATACTTGGC } \\
\text { R: GGGCGTTCTGATAAGGGA }\end{array}$ & $460-482$ & 59 & 7 & 4.5 & 0.52 & 0.78 & 0.74 & $0.000 *$ \\
\hline HD44 & KC506611 & $(\mathrm{AC})_{22}$ & $\begin{array}{l}\text { F: AGCCTGCCTTTGCTACAC } \\
\text { R: CCTACTGGTGGCTCTGGT }\end{array}$ & $93-118$ & 57 & 9 & 4.9 & 0.53 & 0.80 & 0.77 & $0.000 *$ \\
\hline HD48 & KC506612 & $(\mathrm{CA})_{7}\left(\mathrm{CA}_{20}\right.$ & $\begin{array}{l}\text { F: AACATGCTGGCCGTATCTG } \\
\text { R: AGCCTGCCTGATTAAGCG }\end{array}$ & $438-476$ & 59 & 5 & 1.9 & 0.44 & 0.48 & 0.40 & 0.4584 \\
\hline HD55 & KC506613 & $(\mathrm{CA})_{19}$ & $\begin{array}{l}\text { F: CTGTCCACCTTGCTCACT } \\
\text { R: ATAGATCTGCAGGCTCGG }\end{array}$ & $37-129$ & 56 & 11 & 8.6 & 0.58 & 0.89 & 0.87 & $0.000 *$ \\
\hline HD56 & KC506614 & $(\mathrm{CA})_{6}$ & $\begin{array}{l}\text { F: AATGAGAAATAAACAGCAGGAC } \\
\text { R:CAGCCTGACCTAGAACCATC }\end{array}$ & $222-258$ & 55 & 6 & 1.8 & 0.28 & 0.45 & 0.42 & 0.0245 \\
\hline HD71 & KC506615 & $(\mathrm{AG})_{13}$ & $\begin{array}{l}\text { F: CAATGAAACAGTTGAAGAGCAGC } \\
\text { R: ATCCCTCACTGTCGCCCTC }\end{array}$ & $483-521$ & 59 & 9 & 5.9 & 0.45 & 0.84 & 0.81 & $0.000^{*}$ \\
\hline HD85 & KC506617 & $(\mathrm{GA})_{15}$ & $\begin{array}{l}\text { F: TACCAAGGGTGTAAATAAGC } \\
\text { R: ACGGAGCAATGTCAAGTGT }\end{array}$ & $503-551$ & 54 & 4 & 1.8 & 0.44 & 0.43 & 0.36 & 0.6907 \\
\hline HD118 & 8 KC506618 & $(\mathrm{AG})_{25}$ & $\begin{array}{l}\text { F: GGTTCAGTCCTCCCTGCCTCT } \\
\text { R: TGCTCCCGCTAACAAAGG }\end{array}$ & $349-357$ & 61 & 3 & 1.1 & 0.03 & 0.05 & 0.05 & 0.0408 \\
\hline HD127 & 7 KC506619 & $(\mathrm{AG})_{5}$ & $\begin{array}{l}\text { F: AAGAGGGTGGACTGATGG } \\
\text { R: AGGGTTGCGTCAGGTTTC }\end{array}$ & $228-268$ & 58 & 10 & 4.9 & 0.78 & 0.80 & 0.77 & 0.3265 \\
\hline HD143 & 3 KC506621 & $(\mathrm{AG})_{10}(\mathrm{AG})_{11}$ & $\begin{array}{l}\text { F: TACATTTGTGGTGGTGGC } \\
\text { R: AAAGCAGCAAACTCATCG }\end{array}$ & 168-196 & 56 & 11 & 8.8 & 0.51 & 0.89 & 0.88 & $0.000 *$ \\
\hline HD154 & 4 KC506622 & $(\mathrm{GA})_{14}$ & $\begin{array}{l}\text { F: CATGAGGGGAACAGGGAG } \\
\text { R: TCGGACCTAATCTGTGCTG }\end{array}$ & $256-302$ & 57 & 9 & 6.8 & 0.45 & 0.86 & 0.84 & $0.000 *$ \\
\hline HD160 & 0 KC506623 & $(A G)_{18}(A G)_{17}$ & $\begin{array}{l}\text { F: CACTTTGTCCTTGACCCTT } \\
\text { R: AGGGGTTATTTCAGAGCAG }\end{array}$ & $124-186$ & 53 & 12 & 8.3 & 0.67 & 0.89 & 0.87 & $0.000^{*}$ \\
\hline Mean & & & & & & 7.9 & 4.6 & 0.49 & 0.68 & 0.64 & \\
\hline
\end{tabular}

The $H_{\mathrm{O}}$ of each locus ranged from 0.03 (HD118) to 0.78 (HD127), with an average of 0.49. The $H_{\mathrm{E}}$ of each locus ranged from 0.05 (HD118) to 0.89 (HD25, HD55, HD143, and HD160), with an average of 0.68 . Based on the polymorphic index content (PIC) values for each locus, 1 locus (HD118) exhibited low polymorphism (PIC < 0.25), 5 loci (HD16, HD28, HD48, HD56, and HD85) were moderately polymorphic $(0.25<$ PIC $<0.5)$, and the other 14 loci were highly polymorphic (PIC $>0.5$ ). None of the loci exhibited significant linkage disequilibrium. After sequential Bonferroni correction for multiple tests, 11 loci were found to depart significantly from the Hardy-Weinberg equilibrium (HWE). Further tests indicated that heterozygote deficiency at these loci was responsible for this departure. Another possible 
explanation for the departure from the Hardy-Weinberg equilibrium is the dramatic decline in C. ectenes spawning populations, and non-random mating or genetic bottlenecks.

\section{CONCLUSIONS}

In the present study, a microsatellite-enriched genomic library was constructed for $C$. ectenes, with a total of 20 novel genomic microsatellite DNA markers being developed. These microsatellite markers are expected to facilitate the management and exploration of the genetic resources of $C$. ectenes, and to assist in the genetic improvement of aquaculture bred populations.

\section{ACKNOWLEDGMENTS}

Research supported by the China Agriculture Research System (\#CARS-50), the National High Technology Research and Development Program (\#2012AA10A413), and the National Key Technology R\&D Program (\#2012BAD17B03).

\section{REFERENCES}

Botstein D, White RL, Skolnick M and Davis RW (1980). Construction of a genetic linkage map in man using restriction fragment length polymorphisms. Am. J. Hum. Genet. 32: 314-331.

Chen F, Zeng L and Cheng Q (2012). Development of thirty-four novel polymorphic microsatellite markers in Coilia ectenes (Clupeiformes: Engraulidae) and cross-species amplification in two closely related taxa. J. Genet. 91: e37-e43.

Cheng QQ and Han J (2004). Morphological variations and discriminant analysis of two populations of Coilia ectenes. J. Lake Sci. 16: 356-364.

Cheng QQ, Lu DR and Ma L (2005a). Morphological differences between close populations discernible by multivariate analysis: a case study of genus Coilia (Teleostei: Clupeiforms). Aquat. Living Resour. 18: 187-192.

Cheng QQ and Lu DR (2005b). PCR-RFLP analysis of cytochrome b gene does not support Coilia ectenes taihuensis being a subspecies of Coilia ectenes. J. Genet. 84: 307-310.

Cheng Q, Cheng H, Wang L, Zhong Y, et al. (2008). A preliminary genetic distinctness of four Coilia fishes (Clupeiformes: Engraulidae) inferred from mitochondrial DNA sequences. Genetika 44: 395-400.

Feng ZX (1997). Ichthyology. 2nd edn. China Agriculture Press, Beijing.

Li Q and Wan JM (2005). SSRHunter: development of a local searching software for SSR sites. Yi Chuan 27: 808-810.

Li YX, Xie SG, Li ZJ and Gong WB (2007). Gonad development of an anadromous fish Coilia ectenes (Engraulidae) in lower reach of Yangtze River, China. Fish. Sci. 73: 1224-1230.

Liao MJ, Yang GP, Wang XC, Wang DQ, et al. (2007). Development of microsatellite DNA markers of silver carp (Hypophthalmichthys molitrix) and their cross-species application in bighead carp (Aristichthys nobilis). Mol. Ecol. Notes 7: 95-99.

Liu W (1995). Biochemical and morphological comparison and interspecific relationships of four species of the genus Coilia in China. Oceanologia et Limnologia Sinica 26: 565-568.

Ma CY, Cheng QQ, Zhang QY, Zhuang P, et al. (2010). Genetic variation of Coilia ectenes (Clupeiformes: Engraulidae) revealed by the complete cytochrome b sequences of mitochondrial DNA. J. Exp. Mar. Biol. Ecol. 385: 14-19.

Ma CY, Cheng QQ and Zhang QY (2011). Development of 12 polymorphic microsatellite markers in Coilia ectenes Jordan and Seale, 1905 (Clupeiformes: Engraulidae) and cross-species amplification in Coilia mystus Linnaeus, 1758. Environ. Biol. Fish. 91: 243-249.

Qu NN, Gong SY, Huang GJ, Tong JG, et al. (2010). Isolation and screening of microsatellite markers from the Chinese pearl oyster Pinctada fucata based on FIASCO. J. Trop. Oceanogr. 29: 47-54.

Rice WR (1989). Analyzing tables of statistical tests. Evolution 43: 223-225.

Rousset F (2008). Genepop'007: a complete reimplementation of the genepop software for Windows and Linux. Mol. Ecol. Res. 8: 103-106.

Weber JL (1990). Informativeness of human (dC-dA)n.(dG-dT)n polymorphisms. Genomics 7: 524-530. 
Whitehead PJP, Nelson GJ and Wongratana T (1988). Vol. 7. Clupeoid fishes of the world (Suborder Clupeoidei): An annotated and illustrated catalogue of the herrings, sardines, pilchards, sprats, shads, anchovies and wolf-herrings. Part 2- Engraulidae In: FAO species catalogue. FAO Fisheries Synopsis No. 125, Rome, 470-471.

Yeh FC, Yang RC and Boyle T (1999). POPGENE version 1.31: Microsoft Windows-Based Freeware for Population Genetic Analysis. University of Alberta and Centre for International Forestry Research, Edmonton. Available at [http://www.ualberta.ca/ fyeh/popgene_download.html] Accessed April 20, 2011.

Yuan CM, Lin JB, Qin AL and Liu HR (1976). On the classification history and status of genus Coilia in China. J. Nanjing Univ. (Natural Science Edition) 2: 1-12.

Yuan CM (1980). On the classification of the anchovies, Coilia, from the lower Yangtze River and the southeast coast of China. J. Nanjing Univ. (Mathematical Biquarterly) 3: 67-82.

Yuan CM and Qin AL (1984). Ecological Habits and distribution of Coilia along the Chinese coast and its changes of output. Mar. Sci. 5: 35-37.

Zane L, Bargelloni L and Patarnello T (2002). Strategies for microsatellite isolation: a review. Mol. Ecol. 11: 1-16.

Zheng JS, Liao XL, Tong JG and Wang D (2008). A pilot study on isolation of microsatellite DNA in the Yangze finless porpoise (Neophocaena phocaenoides asiaeorientalis). Acta Hydrobiologica Sinica 32: 25-31. 